\title{
Development of the Human Resources Information System (HRIS) Based on Usability Analysis with Usefulness, Satisfaction, Ease to Use (USE) Questionaire and Cognitive Walkthrough Methods
}

\begin{abstract}
Doni Prastyo ${ }^{1)}$, Sihabudin ${ }^{2)}$, Muhammad Yusuf Bakhtiar ${ }^{3)}$
12) Budi Luhur University

Jl. Raya Ciledug, Pertukangan Utara, Kebayoran Lama, Jakarta Selatan

1)doni.prastyo22@gmail.com ${ }^{2)}$ ihab.khoirun@gmail.com ${ }^{3)}$ bakhtiar_yusuf@hotmail.com
\end{abstract}

\section{INTRODUCTION}

The growing growth in the technology field at the end of this year has made many companies use various technologies for various aspects of the company. One such technology is the HRIS (Human Resource Information System) in the field of employee management, HRIS is an application for storing, processing, and collecting data related to HRD or management of employees.

The HRIS application has a very significant influence on company management. In addition, HRIS can facilitate HRD to manage employees more efficiently so that the objectives of HRD to establish good and mutually beneficial relationships between employees and the company will be achieved. Many features obtained by the company in the use of HRIS, some of these features are making it easier for employees to access salary slips to apply for leave or all permits done online, calculation of compensation rates such as overtime pay, bonuses, and THR can be done accurately without taking a long time, online employee absenteeism and close the possibility of employees cheating in attendance attendance.

QEY-HRIS is a HRIS application product that is useful to help companies achieve their goals in managing their employees well and creating great relationships between employees and companies. So many features are presented in the QEY-HRIS application so education and training are needed in the use of QEY-HRIS. this is done so that employees can use this application properly. In addition, the design of the user interface in the application must also be considered well because the QEY-HRIS application is quite complex so it demands to have a good level of usability so that employees can easily use this application. A good usability level can be measured as employees can use the functionality of the system effectively, efficiently, and satisfactorily in achieving a certain goal.

In most usability studies, they only use one method on usability alone Khoirida (2012), Marthasari (2017), and the results of the study mostly display the results of assessment of the usability of the application without comparing before and after the application was tested Priyo (2016). In previous studies using the cognitive walkthrough method in the method used, using video screen recorder tools to view and record all the tests conducted by respondents, while in this study using an application that can record all actions taken by respondents in real time and summarize the results of testing. 


\section{Research Purposes:}

1. To find out which parts of the user interface need improvement.

2. Facilitate IT Developers to improve applications.

3. Increase the usability of the application user interface so that it is easy to use and application users increase.

\section{II.METHODS}

The author uses the Cognitive Walktrough and USE Questionnaire methods to examine usability user interfaces in the Human Resources Information System (HRIS). The USE Questionnaire method is used to assess the application of the Human Resources Information System (HRIS) by referring to usefulness, satisfaction, and Ease of Use. The results of the assessment can be seen whether the application in terms of its usability is referred to as feasible or not. While the Cognitive Walkthrough Method is used to find out which parts of the application need improvement with a series of testing tasks performed by the respondent.

\subsection{Research Steps}

Following are the steps carried out in this study:

1. Analysis of USE Questionnaire

Analyzing the filling of questionnaires given to customers / clients that are used to determine the weaknesses and strengths of the QEY-HRIS application in managing employees.

2. Cognitive Walkthrough Testing

In this test there are several steps that are carried out, the stages are:

a. Preparation Stages

At this stage include the literature study stage and understand the system to be tested, also compile the scenario of tasks to be carried out.

b. Stage of Execution

At this stage, prepare everything that is done for the testing process and execution for testing directly to the Respondents.

3. Analysis of Test Results

At this stage an analysis of the tests conducted has been carried out. The analysis looks at the success rate of respondents in performing a task, the level of failure or error of the respondent in carrying out a task and seeing the respondent's processing time in completing a task scenario.

4. Repair Identification and Recommendations

After analyzing the usability test results, it is identified the problems faced by respondents when using the application. Problems that arise in each task scenario will be given recommendations for improvements that are prioritized to be carried out immediately.

5. Application Repair according to Repair Recommendations

At this stage the author carries out an application repair in accordance with recommendations for improvements from the previous test. This improvement also adjusts the Respondents' requests and complaints regarding their use in using the QEY-HRIS application. Repairs are carried out on the task scenario that has been tested.

6. Retesting with the Repaired Application

At this stage the author re-tests using the method previously carried out, namely the USE Questionnaire and the Coginitive Walkthrough. Technical Testing is carried out slightly differently than before, if previously the Respondents conducted the Cognitive Walkthrough test at the end after knowing the results of testing the USE Questionnaire, this time the respondents conducted cognitive walkthrough testing first so that users could experience the application that had been repaired after the respondents filled out questionnaires about experience of Respondents in using the application.

7. Final Test Result Analysis

In this stage the author analyzes the test results by using a fixed application. The analytical method used is the same as the previous analysis, namely looking at the success rate of the respondent in completing the task scenario, the Respondent's error rate in completing a task scenario, and the amount of time needed to complete the task scenario. Whereas for the USE Questionnaire method, the analysis is the same as before, namely looking at the average respondent in assessing the questionnaire. 
8. Testing Summary

This stage is the final stage, this stage presents a comparison between before repairs are made after repairs are made. The result is that the usability increases after a system repair? These comparisons include comparisons when testing using the previous cognitive walkthrough method with the present, looking at the success of the respondents, the respondent's mistakes and the time used by the respondents. The end result can be seen by comparison with the previous USE Questionnaire method with the current one, on average the Respondents assessed from the experience of the respondents in performing the task scenario in the improved application.

\subsection{Responden Characteristic}

Respondents of this study included users who were the main target in using HRIS applications, namely several companies that had used QEY-HRIS applications in managing employees. The number of respondents and the characteristics of the respondents chosen can be seen in table 1 .

Tabel 1: Responden Characteristic Table

\begin{tabular}{|c|c|c|c|c|}
\hline No & Profile & Description & Total & $\%$ \\
\hline \multirow[t]{3}{*}{1} & \multirow[t]{3}{*}{ Educations } & SMA & 1 & 10 \\
\hline & & D3/S1 & 9 & 90 \\
\hline & & Total & 10 & 100 \\
\hline \multirow[t]{3}{*}{2} & \multirow[t]{3}{*}{ Gender } & Male & 7 & 70 \\
\hline & & Female & 3 & 30 \\
\hline & & Total & 10 & 100 \\
\hline \multirow[t]{3}{*}{3} & \multirow[t]{3}{*}{ Age } & $17-25$ Years & 5 & 50 \\
\hline & & $26-35$ Years & 5 & 50 \\
\hline & & Total & 10 & 100 \\
\hline \multirow[t]{4}{*}{4} & \multirow[t]{4}{*}{ Experience } & $<2$ Years & 4 & 20 \\
\hline & & $2-5$ Years & 3 & 30 \\
\hline & & $>5$ Years & 3 & 30 \\
\hline & & Total & 10 & 100 \\
\hline
\end{tabular}

\subsection{Responden Characteristic}

In this study the authors explain the instruments used in the data collection process. The instrument used was the application of the ssi test based on the Cognitive Walktrough method because the data collection method was carried out through application testing and questionnaire filling. This application calculates each click made by the Respondent to complete the task scenario, and calculates the time needed by the respondent in completing a task scenario. In addition, after all the task scenarios have been carried out, there will be a button to see the summary or the results of the tests conducted by the respondent. The following indicators are calculated in this test.

1. Error

Error $=$ JK-LS

Information :

JK: Number of clicks made by Respondents

LS: The correct steps are taken by the Respondents

2. Successful Workmanship (\%)

Success $=(\mathrm{LS} / \mathrm{JT}) * 100 \%$

Information :

LS = Step of Success conducted by Respondents

JT $=$ Number of Stages in one Task Scenario

3. Time

The time saved in the system is time in seconds, the length of time the respondent completes a task scenario. 


\section{RESUlTS AND DISCUSSION}

\subsection{USE Questionaire Analysis}

After Resoponden has filled out the questionnaire, the author analyzes the low or high usability in the QEYHRIS application. The results of the analysis can be seen in table 2.

Tabel 2: Table of Usability Analysis Results

\begin{tabular}{|l|c|c|}
\hline Criteria & Total & Average \\
\hline Usefulness & 25 & 3.99 \\
\hline Ease Of Use & 25 & 3.41 \\
\hline Ease Of Learning & 25 & 3.7 \\
\hline Satisfaction & 25 & 3.57 \\
\hline All & 25 & $\mathbf{3 . 6 7}$ \\
\hline
\end{tabular}

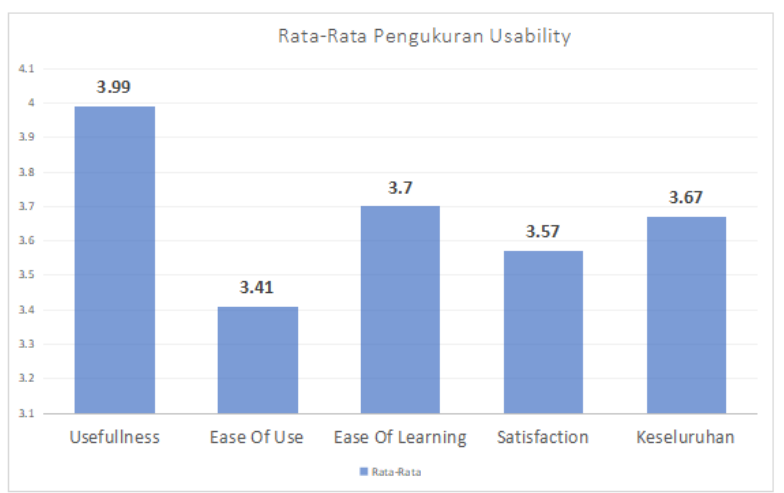

Figure 1: Average Usability measurement chart

From Figure 1, it can be seen that the overall value of usability shows a value of 3.67 on a scale of $1-5$. This shows that the usability level is still standard so it is necessary to develop the system so that usability in the application increases. Each Ease of use (3.41), Ease of learning (3.7), and Satisfactions (3.57) criteria still have standard values. Ease of Use has the lowest value (3.41) while Usefulness (3.99) has the highest value of all criteria. 


\subsection{Test Result Cognitive Walkthrough}

After all respondents tested the QEY-HRIS application. The author analyzes to see the extent to which the respondents interacted with the QEY-HRIS application, looked at the completion of the task, the number of errors made, and the amount of time needed to complete the task.

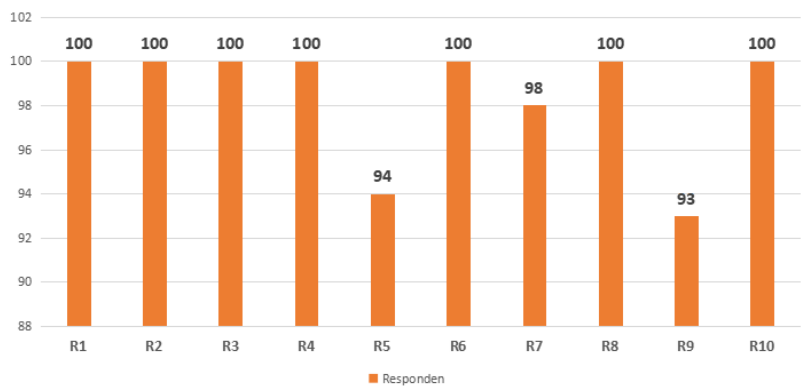

Figure 2: Diagram of the number of respondents who successfully completed the task scenario (\%)

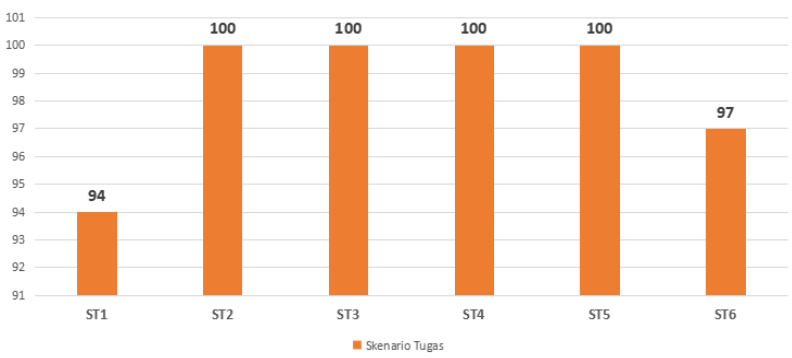

Figure 3: Diagram of the number of task scenarios completed by respondents (\%)

In Figure 2 and Figure 3 shows that the level of task completion is measured based on the task scenario that is completed correctly in accordance with the stages recommended by the respondent. Seeing from the picture shows (task scenario 1) that Attendance Detail is not completed by the respondent by (94\%) the lowest compared to other task scenarios. From all tasks only 2 task scenarios that were not successfully completed were task 1 scenario and task scenario 6 employee attendance details and added and edited employee salary. There are only 3 Respondents who did not succeed in completing the entire task, namely respondents 5, 7, and 9. And the lowest did not complete the task scenario correctly, namely the respondents 9 (93\%). The level of task completion is a measure of the number of resolutions successfully completed by the respondent for each task (George 2008). The usability results show that not all task scenarios can be completed correctly, in the figure there are task scenarios that can be completed correctly and cannot be completed correctly by the respondent.

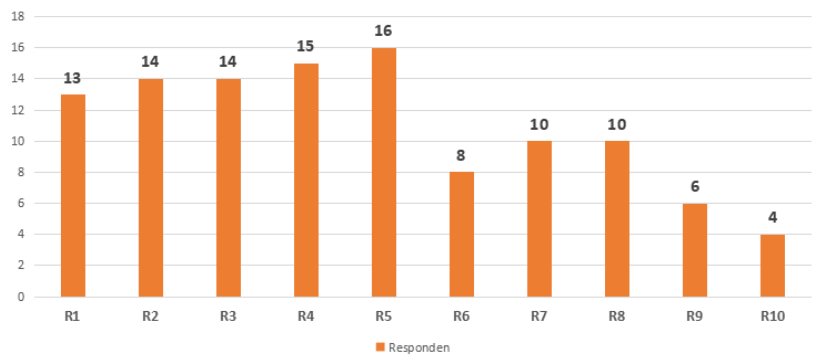

Figure 4: Number diagram of errors made by respondents (times) 


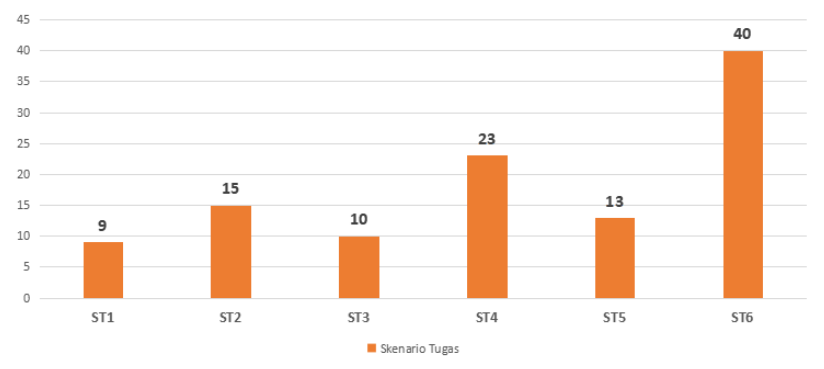

Figure 5: Amount of error diagram for each task scenario (times)

In Figure 4 shows that respondents 8 made the most mistakes (16 times) compared to other respondents, and the respondents who made the lowest mistakes were respondents 10 (4 times). In the picture shows all respondents must have made mistakes in completing the task scenario. In Figure 5, it shows that the task scenario that has the least error is in the task scenario 1 (9 times), which is on Employee Attendance Details. The most frequently done task scenario is the task scenario 6 (40 times), namely Add and Update Basic Employee Salary.

Table 3: Table of Amount of Time for completion of the Task scenario

\begin{tabular}{|l|c|l|l|l|l|l|}
\hline \multicolumn{1}{|c|}{ Rspn } & ST1 & ST2 & ST3 & ST4 & ST5 & ST6 \\
\hline R1 & 146 & 138 & 129 & 40 & 97 & 106 \\
\hline R2 & 69 & 110 & 80 & 116 & 94 & 58 \\
\hline R3 & 164 & 109 & 124 & 53 & 130 & 81 \\
\hline R4 & 74 & 114 & 234 & 56 & 118 & 78 \\
\hline R5 & 75 & 54 & 41 & 42 & 104 & 11 \\
\hline R6 & 69 & 80 & 56 & 237 & 90 & 76 \\
\hline R7 & 177 & 158 & 106 & 17 & 24 & 172 \\
\hline R8 & 73 & 42 & 33 & 69 & 125 & 29 \\
\hline R9 & 38 & 41 & 34 & 21 & 327 & 41 \\
\hline R10 & 24 & 18 & 37 & 57 & 32 & 19 \\
\hline Rata & 90.9 & 86.4 & 87.4 & 70.8 & 114.1 & 67.1 \\
\hline MIN & 24 & 18 & 33 & 17 & 24 & 11 \\
\hline MAX & 177 & 158 & 234 & 237 & 327 & 172 \\
\hline
\end{tabular}

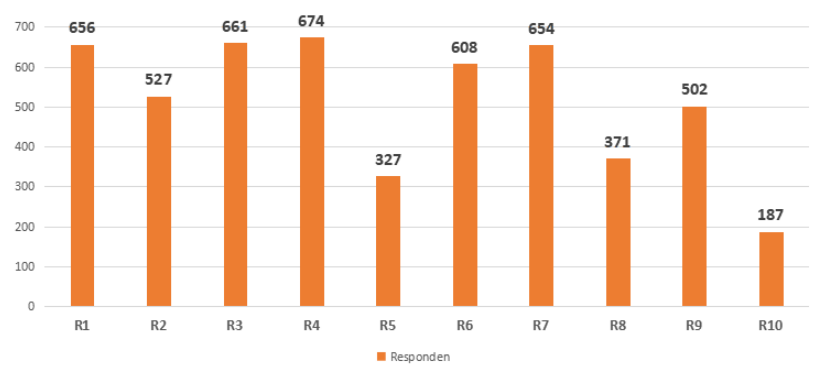

Figure 6: Diagram of the amount of time used by the Respondent to do the Task Scenario (seconds) 


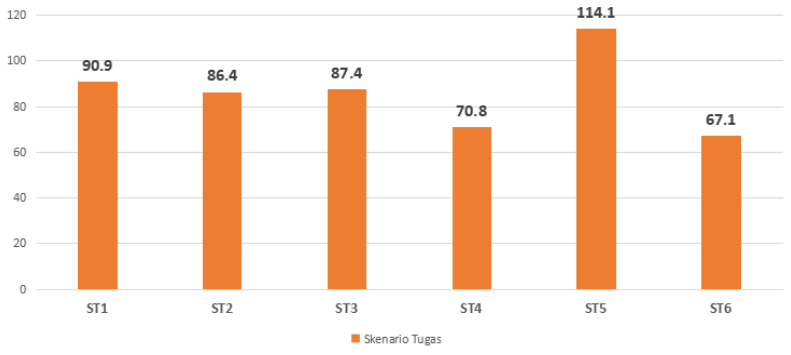

Figure 7: Average time diagram per task scenario (seconds)

In table 3 is the breakdown of the time the respondent did to carry out testing while seen in Figure 6, shows that respondent 4 had the longest time that is (674 seconds), while the fastest was respondent 10 which was (187 seconds). And in Figure 7 shows that the task scenario that has the longest average time is the Task Scenario 5 Employee Status Update which is (114.1 Seconds) while the fastest scenario is scenario 6, Add and edit employee salary which is (67.1 seconds).

\subsection{Repair Recommendation}

Based on the explanation described in usability analysis by looking at the completion parameters in the task scenario, the errors found in the task scenario, and the time taken in completing the task scenario, it is necessary to make improvements. Some of the improvement recommendations can be seen in table 4 .

Table 4: Table of Repair Recommendations

\begin{tabular}{|c|c|c|c|}
\hline ST & Modul & Problem & Repair Solution \\
\hline ST1 & $\begin{array}{l}\text { Attendance } \\
\text { Details }\end{array}$ & $\begin{array}{l}\text { 1. When pressing the import data } \\
\text { attendance button, the import process } \\
\text { loads a new page so that it takes a long } \\
\text { time. } \\
\text { 2. This module has little content that can } \\
\text { be added with other content }\end{array}$ & $\begin{array}{l}\text { 1. When you press the import button, a } \\
\text { popup/capital will appear so you don't have } \\
\text { to load the page. } \\
\text { 2. This module will be combined with the } \\
\text { recap attendance module, so there are not } \\
\text { many pages to upload attendance. }\end{array}$ \\
\hline ST2 & $\begin{array}{l}\text { Data Recap } \\
\text { Attendance }\end{array}$ & $\begin{array}{l}\text { When selecting Combobox, you still } \\
\text { need to press the data processing button } \\
\text { to display data }\end{array}$ & $\begin{array}{l}\text { When selecting the combo box the table will } \\
\text { automatically change according to the selected } \\
\text { data in the combobox. }\end{array}$ \\
\hline ST3 & $\begin{array}{l}\text { Employee } \\
\text { Payroll Data }\end{array}$ & $\begin{array}{l}\text { 1. Load old payroll data not yet using } \\
\text { datatable side sarver } \\
\text { 2. It is necessary to press the data } \\
\text { process to process the process } \\
\text { indirectly when selecting the combo } \\
\text { box option }\end{array}$ & $\begin{array}{l}\text { 1. Using a server side system so that data load } \\
\text { can be processed quickly. } \\
\text { 2. When selecting a datatable combo box it } \\
\text { will automatically change according to } \\
\text { choice, no need to press the process button. }\end{array}$ \\
\hline
\end{tabular}

\subsection{Application Repair}

After several tests on the QEY-HRIS application, the author made application improvements in accordance with several recommendations from testing the Cognitive Walktthrough method. This improvement will be expected to be able to answer complaints and inputs that have been submitted during the previous testing. The following are some of the application model designs that have been repaired in accordance with recommendations for improvements from the previous test can be seen in Figure 8. 


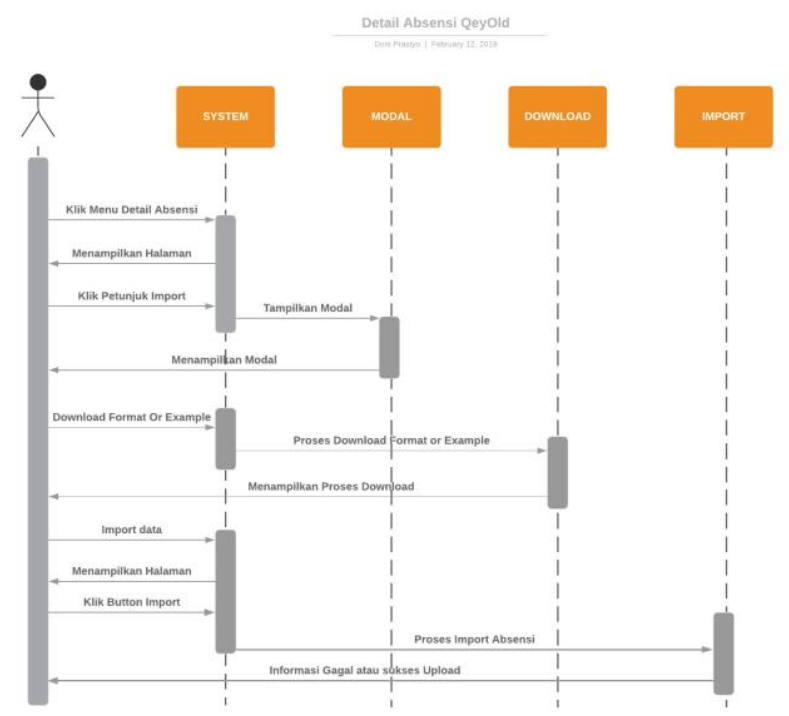

Figure 8: Sequence Diagram Module Time Attendance Before Repairing

In addition, the following is the appearance of the application from before repairing and after repairing, can be seen in Figure 9 and Figure 10.

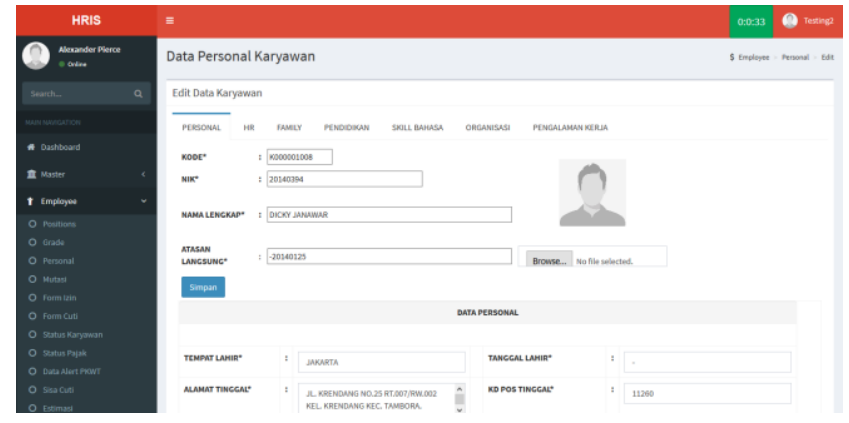

Figure 9: Old Display Module Employee Status Update

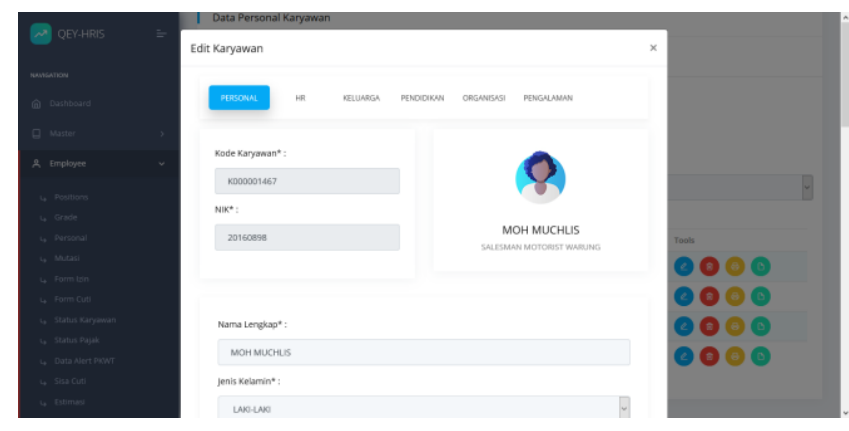

Figure 10: Latest Views of the Employee Status Update Module 


\subsection{After Improved Cognitive Walkthrough Test}

The author analyzes the test using the technical that had previously been done. The Cognitive walkthrough method analyzes the same as before, namely seeing the success rate of the Respondents in completing the task scenario, seeing the level of errors made by the Respondents in completing the task scenario, and the time taken to complete the task scenario. While the USE Questionnaire is also the same as before, namely looking at the average respondent in assessing the application. And here are the results of analysis of the application that has been fixed :

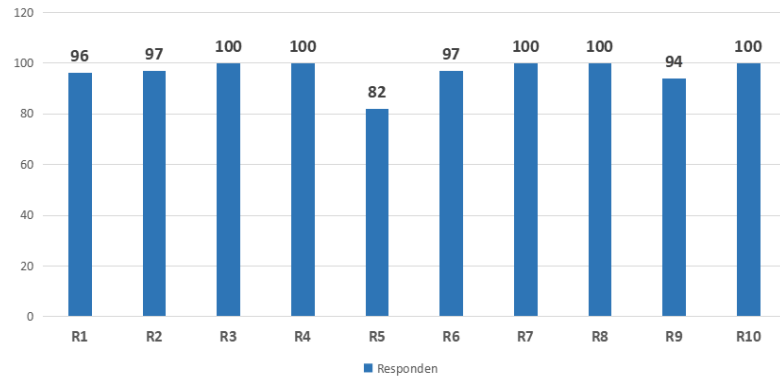

Figure 11: Diagram of the number of respondents completing the task scenario (\%)

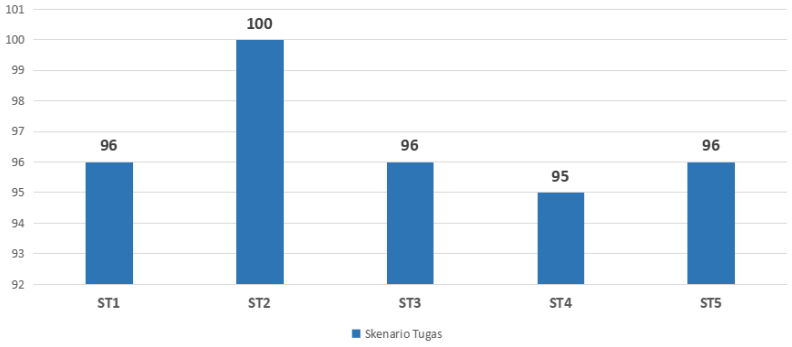

Figure 12: Diagram of the Task Scenario assessed by Respondents (\%)

In Figure 11 and Figure 12 shows that (task scenario 4) is the update of employee status not completed by the respondent at (95\%) the lowest compared to other task scenarios. Only one task scenario that can be completed properly is task scenario 2 , the payroll process can be completed by $100 \%$. There were 5 respondents who succeeded in completing the entire task, namely respondents $3,4,7,8$ and 10 . And the lowest did not complete the task scenario well, namely the respondents $5(82 \%)$.

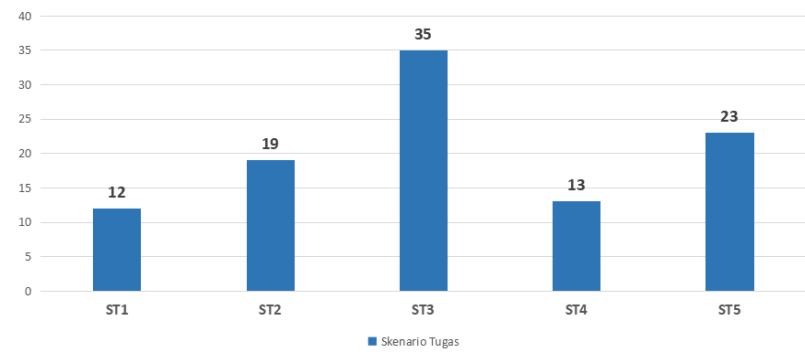

Figure 13: Amount of Error Diagram Each Task Scenario (times) 


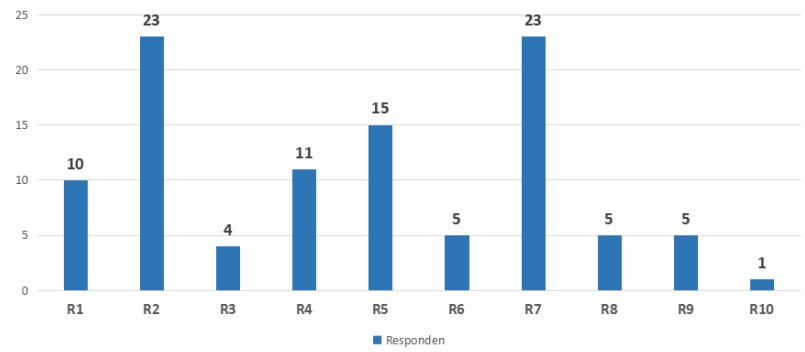

Figure 14: Number of Respondent Error Diagrams (times)

In Figure 13 shows that the task scenario that has the least error is in the task scenario 1, that is (12 times) uploading employee absences, while the one with the most errors when doing the task is task 3 scenario (35 times) Add New Employees. In Figure 14 shows that the respondents who made the least mistakes in completing the task scenario were respondents 10 (1), and the most mistakes in completing the task scenario were respondents 2 and 7 (23 times).

Table 5: Table of Amount of Time for completion of the Task scenario

\begin{tabular}{|l|c|c|c|c|c|c|}
\hline Rspn & ST1 & ST2 & ST3 & ST4 & ST5 & Total \\
\hline R1 & 194 & 81 & 60 & 78 & 55 & 468 \\
\hline $\mathbf{R 2}$ & 58 & 58 & 244 & 62 & 69 & 491 \\
\hline $\mathbf{R 3}$ & 159 & 90 & 69 & 83 & 89 & 490 \\
\hline $\mathbf{R 4}$ & 160 & 95 & 114 & 80 & 52 & 501 \\
\hline $\mathbf{R 5}$ & 30 & 32 & 24 & 14 & 12 & 112 \\
\hline R6 & 138 & 90 & 160 & 51 & 43 & 482 \\
\hline R7 & 154 & 108 & 15 & 70 & 59 & 406 \\
\hline R8 & 122 & 71 & 69 & 66 & 95 & 423 \\
\hline R9 & 33 & 36 & 94 & 64 & 32 & 259 \\
\hline R10 & 34 & 36 & 13 & 19 & 21 & 123 \\
\hline Rata & 108.2 & 69.7 & 86.2 & 58.7 & 52.7 & 375.5 \\
\hline MIN & 30 & 32 & 13 & 14 & 12 & 112 \\
\hline MAX & 194 & 108 & 244 & 83 & 95 & 501 \\
\hline
\end{tabular}

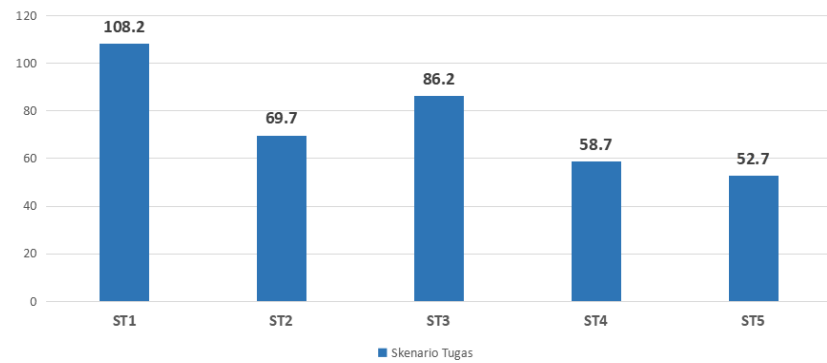

Figure 15: Average number of time diagrams (seconds) 


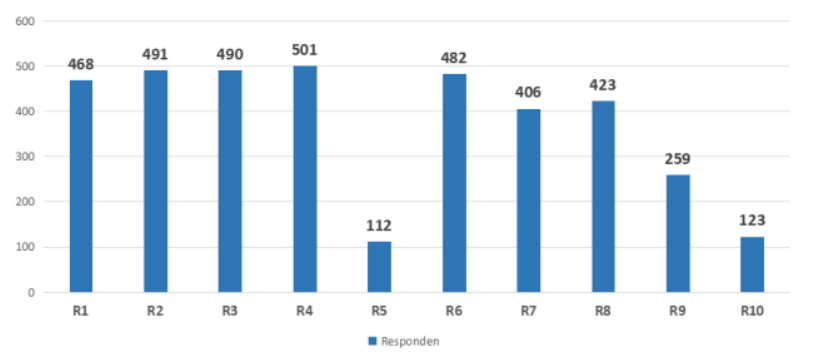

Figure 16: Diagram of the amount of time used (seconds)

In table 5 is a detailed breakdown of the time respondents did in completing a task scenario. in Figure 15 shows that the task scenario that has the longest average time is the Task Scenario 1 Upload Attendance that is (108.2 seconds) while the average scenario that is the fastest is scenario 5, the loan is (52.7 seconds). And in figure 15, shows that respondents 4 have the longest time that is ( 501 seconds), while the fastest is respondent 5 which is (112 seconds).

\subsection{Analyze USE Questionaire After Repairing}

After Resoponden has tested the application that has been repaired. The following results from Analysis of the USE Questionnaire can be seen in Table 6 and Figure 17.

Table 6: Table of Usability Analysis Results after Improved

\begin{tabular}{|l|c|c|}
\hline Criteria & Total & Average \\
\hline Usefulness & 25 & 4.21 \\
\hline Ease Of Use & 25 & 3.61 \\
\hline Ease Of Learning & 24 & 4.18 \\
\hline Satisfaction & 25 & 4.04 \\
\hline All & 25 & $\mathbf{4 . 0 1}$ \\
\hline
\end{tabular}

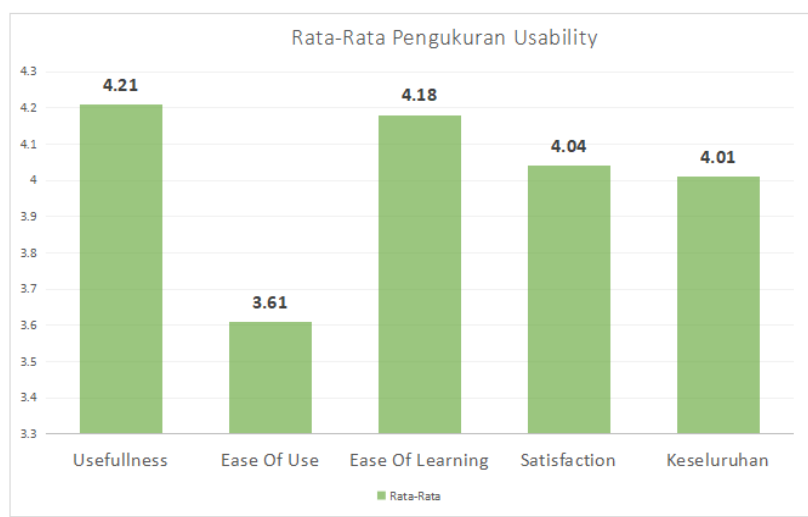

Figure 17: Average diagram of usability measurements

In table 6 shows the details of the usability analysis using the USE Questionnaire method. And in Figure 17 it can be seen that the overall value of usability shows a value of 4.01 from a scale of 1-5. This shows that the usability level is good. Each of the Usefulness criteria (4.21), Ease of use (3.61), Ease of learning (4.18), and Satisfactions (4.04) already have good usability.

\subsection{Testing Summary}


After conducting various tests and analyzes from before the system is repaired and after the system is repaired, the author will compare the results of the test so that it can be seen whether the usability of the application has increased or not can be seen in Figure 18.

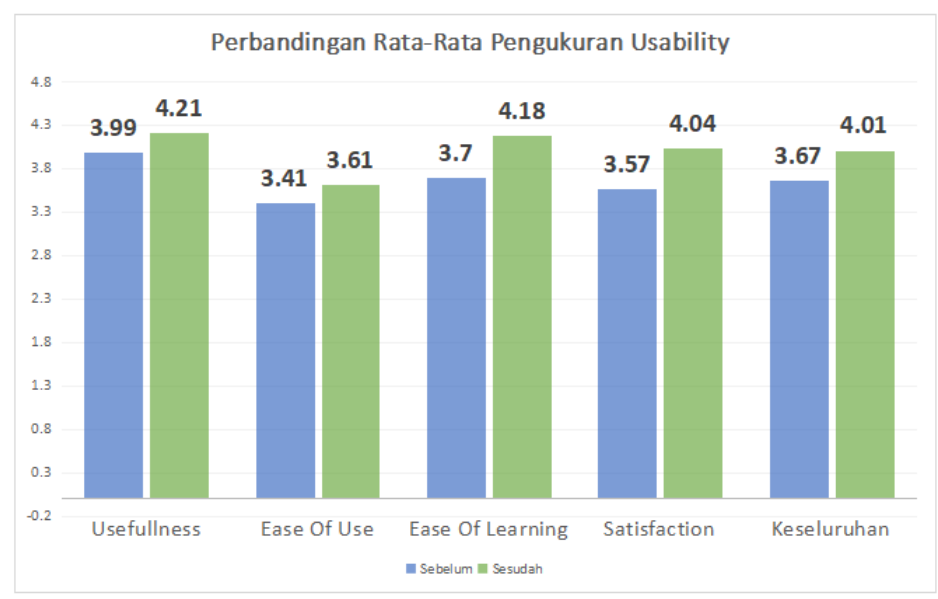

Figure 18: Comparison diagram of average usability measurements

In Figure 18 shows that from all usability categories from before to after the system improvement has increased on the usefulness criteria has increased from the original of 3.99 up to 4.21, Ease of Use also experienced an increase which is from 3.41 to 3.61 , Ease of learning experiences also experienced from 3.7 to 4.18 , the Satisfactions criteria also increased from 3.57 to 4.04. If total overall usability criteria has increased, from the previous one of 3.67 to 4.01 (increase of 0.34). After repairing the total usability is 4.01 on a scale of 1-5, this shows that the criteria fall into the "AGREE" category. The usability experienced a significant increase from all criteria so that it was expected to facilitate users in using this application.

\section{CONCLUSIONS}

In the course of the QEY-HRIS application there are several complaints from customers regarding the performance of the application, Analysis using Usefulness, Satisfactions, Ease to Use (USE) Questionnaire tells us that the QEYHRIS application has a low usability, so it requires a system to improve usability from the application.

Testing with the cognitive walkthrough method is used to analyze and identify problems faced by users when using the application. Tests in the form of task scenarios that must be completed by the respondent. The author tested 10 respondents including $70 \%$ male and 30\% female, age of respondent was 17-25 years by 50\%, 26-35 years and 50\%. respondent's education is $10 \%$ high school and $90 \%$ D3 / S1, respondent's working experience is <2 years by $40 \%, 2-$ 5 years by $30 \%$, and $>5$ years by $30 \%$.

The test results before the improvement show that the application usability level is 3.67 on a scale of 1-5, with Usefulness (3.99), Ease of Use (3.41), Ease of Learning (3.7), and Satisfaction (3.57). this is still categorized as low usability. And after doing a system improvement based on usability testing with the cognitive walkthrough, the results were 4.04 on a 1-5 scale, with usefulness (4.21), Ease of Use (3.61), Ease Of Learning (4.18) and Satisfactions (4.04). This shows the increase in usability of the overall criteria from the initial average usability of 3.67 up to 4.04 (up by $0.34)$. 


\section{REFERENCES}

[1]. Andrie. P.H. 2017, Perbandingan Metode Evaluasi Usability Studi Kasus Penggunaan perangkat Smart Phone, Teknoin, Vol 23 No. 1

[2] Freddy, P. dan Antonio, P.S. 2016, A Systematic Mapping Review of Usability Evaluation Methods for Software Development Process, International Journal of Software Engineering and Its Applications, Vol. 10, No. 1 (2016), pp. 165-178.

[3] George, CA. 2008, User-centred libraray website : usability evaluation methods, Oxford(UK), Chandos Publishing.

[4] Kadir, Abdul. 2015. Konsep Tuntutan Praktis Basis Data. Yogyakarta: Andi Publisher

[5] Khoirida. Aelani. dan Falahah. 2012, Pengukuran Usability Sistem Menggunakan USE Questionnaire (Studi Kasus Aplikasi Perwalian Online STMIK AMIK Bandung), Seminar Nasional Aplikasi Teknologi Informasi, ISSN: 1907-5022.

[6] Lund, Arnold M, "Measuring Usability with the USE Questionnaire", Usability and User Experience, STC Community. Diakses dari :http://www.stcsig.org/usability/newsletter/0110_measuring_with_use.html, tanggal : 14 Januari 2019 .

[7] Marthasari. Indah. Hayatin. Nur. 2017, Analisis Usability terhadap sistem lective gegulang berbasis USE Questionaire, Seminar Nasional Teknologi dan Rekayasa (SENTRA), ISSN: 2527-6042

[8] Muchtar. P.S. dan Eric, M.A. 2018, Evaluasi User Experience pada Game Left 4 Dead 2 menggunakan Cognitive Walktrough, Jurnal Pengembangan Teknologi Informasi dan Ilmu Komputer Vol 2. Universitas Brawijaya

[9] Nurhayati, Yati. 2015. Fakultas Hukum Prospek Karier Sarjana Hukum. Jakarta: Gramedia

[10] Priyo, R., Wisnu. A.K. dan Heru. S. 2012, Uji Usability Dengan Metode Coginitive Walktrough pada Situs Web Perpustakaan Universitas Mercubuana Jakarta, Jurnal Pustakawan Indonesia, Vol 15 No. 1-2

[11] Reza. K, Misagh. Z.E. dan Yunes. J. 2016, Comparison of Heuristic and Cognitive Walktrogh usability evaluation method for evaluating health Information Systems, Journal of the American Medical Informatics Association Advance Access

[12] Suci. I.I. 2015, Analisis Usabilitas Sistem Informasi Managemen Penerimaan Koleksi Deposit di Perpustakaan Nasional Berdasarkan Pendekatan Evaluasi Heuristik, Tesis, M.Kom, Institut Pertanian Bogor (IPB), Bogor.

[13] Sule, Tisnawati. E dan Wahyuningtyas R. 2015. Manajemen Telenta Terintegrasi. Yogyakarta: Andi Publisher.

[14] Tolle, Herman, Dkk. 2017. Pengembangan Aplikasi Perangkat Bergerak. Malang: UB Press.

[15] Umar, Husein. 2003. Metode Riset Bisnis. Jakarta: Gramedia Massachusetts.

[16] Yusuf. Y.O. dan Suyoto. 2016, Pengujian Usability Antarmuka Aplikasi Mangente, Tesis, M.Kom, Universitas Atma Jaya, Yogyakarta.

[17] ZabedAhmed. S.M. 2008, A Comparison of Usability Technique for evaluating information Retriveral System Interfaces, Performance Measurement and Matrics, Vol 9 No.1 pp 48-58 